\title{
Combined Lung Carcinoma
}

National Cancer Institute

\section{Source}

National Cancer Institute. Combined Lung Carcinoma. NCI Thesaurus. Code C7591.

A lung carcinoma characterized by the presence of large or small neuroendocrine

carcinoma cells in combination with malignant glandular or squamous epithelial cells. 